\title{
Lost British Dragonflies
}

\author{
Norman Moore
}

The large blue butterfly Maculinea arion is probably extinct in Great Britain. Many other of Britain's 56 butterfly species have declined since 1945 , but no other species has become extinct. By contrast, no fewer than four of Britain's 41 resident dragonfly species have almost certainly become extinct since that date. ${ }^{2}$ What are the causes and what lessons can be learnt from these losses?

The lost species include one dragonfly and three damselflies. One species, the dainty coenagrion Coenagrion scitulum, was not discovered until 1946. It was confined to one pond in Essex, which became flooded by sea water in the great floods of 1953. Thus, this species was exterminated by natural causes. The other three were lost as the result of human activities.

The Norfolk coenagrion Coenagrion armatum was confined to ditches and pools in a small area of the Norfolk Broads. This area has been increasingly subjected to a lowering of the watertable which caused the disappearance or profound modification of the habitats on which this species depended. It is also possible that it was affected by pollution of its habitat by phosphates. Despite careful searches the species has not been seen since 1957.

The orange-spotted emerald $O x y$ gastra curtisii is a spectacular green and orange dragonfly which was discovered on Parley Heath in Hampshire in 1820 . Subsequently it was found to occur in southern France and Spain and occasionally elsewhere. It survived in the West Moors River until about 20 years ago when it disappeared after a sewage farm was built upstream of its locality. It was almost certainly exterminated by effluent from the sewage farm.

The scarce green lestes Lestes dryas was found in a number of marshy, shallow ponds and ditches in Essex, the Fens and Romney Marsh, up till the late $1940 \mathrm{~s}$. It became increasingly rare in the 1950s and 1960 s and has not been seen for several years in Britain, although it still occurs in a few localities in west Ireland. Its disappearance has followed drainage improvements and the lowering of watertables in its known localities.

Several lessons can be learnt from this sad story. First, once a species becomes confined to one or very few localities it is extremely vulnerable to accidents, whether these are natural as in the case of the dainty coenagrion, or man-made as in the case of the orange-spotted emerald. A study of the old scarce green lestes sites shows that some are again suitable for this species but they have not been recolonized, presumably because the nearest sources for recolonization (Ireland and nearby continental Europe) are too far distant. ${ }^{3}$

The loss of three of these dragonflies draws attention to the precarious position of species which are dependent on shallow water habitats, since these are particularly vulnerable to drainage and water extraction schemes. Therefore, we should keep a close watch on other species which prefer shallow water, notably the ruddy sympetrum Sympetrum sanguineum and the variable coenagrion Coenagrion pulchellum, both of which still occur in the intensively cultivated lowlands of England, and the heathland species: the southern coenagrion Coenagrion mercuriale, the scarce ischnura Ischnura pumilio and the small red damselfly Coenagrion tenellum which live in shallow bog pools or rivulets. All these species are to be found in national nature reserves, but they cannot be considered safe until more of their localities are conserved in reserves which are managed specifically in order to conserve their habitats. 
Dragonflies are essentially tropical insects and none of those present in Britain are endemic, so why should we be concerned that some of our few species have become extinct? The answer is simply that many dragonfly species, including all those that have become extinct in Britain, are quite local in their total distribution, and they are all under threat in other parts of their range as well. ${ }^{1}$ Therefore, unless every country attempts to conserve its own species they are likely to become greatly reduced in the world as a whole, and some will become totally extinct. What is happening to dragonflies should act as a warning to those concerned with the conservation of other aquatic animals which are less well known.

\section{References}

1. DUMONT, H.J. 1971. Need for protection of some European dragonflies. Biol. Cons. 3: 223-228.

2. MOORE, N.W. 1976. The conservation of Odonata in Great Britain. Odonatologica 5: 38-44.

3. MOORE, N.W. 1980. Lestes dryas Kirby - a declining species of dragonfly (Odonata) in need of conservation: notes on its status and habitat in England and Ireland. Biol. Cons. 17: 143-148.

Professor Norman Moore, The Nature Conservancy Council, 19/20 Belgrave Square, London SW1P 8PY.

\section{Newly Protected Plants in Britain}

\section{Richard Fitter}

The new Wildlife and Countryside Act has protected 42 more wild plants throughout Britain, in addition to 20 of the 21 described in Oryx, May 1981. The one omitted, mezereon Daphne mezereum, is now considered to be out of danger - I know of three or four sites in the Chilterns alone.

Of the new species only one is a fern, Cystopteris dickieana, which grows in one or two sea caves in the east coast of Scotland. There are also two shrubs, the Plymouth pear Pyrus cordata, confined to a few hedges round Plymouth, and wild cotoneaster Cotoneaster integerrimus, a speciality of the limestone headland of the Great Orme behind Llandudno. Four orchids form the largest group of the remaining 39 plants, to add to the five already protected: both the early and late spider orchids Ophrys sphegodes and $O$. fuciflora, confined to chalk turf from Kent to Dorset and in East Kent respectively; the fen orchid Liparis loeselii, rare in East Anglia and South Wales; and the lizard orchid
Himantoglossum hircinum, a speciality of the Kentish dunes which unexpectedly appeared recently on a nature reserve only a mile or two outside a city boundary in the centre of England. There are also two members of the Lily Family, round-headed leek Allium sphaerocephalon, confined to the limestone rocks of the Avon Gorge at Bristol, and whorled Solomon's seal Polygonatum verticillatum, in the north, mainly in Perthshire, as well as one member of the Iris Family, the wild gladiolus Gladiolus illyricus, which still grows under bracken in the New Forest in those few spots where the gipsies cannot find it to sell in the local markets.

Two more groups are three broomrapes and three sedges. The broomrapes, those extraordinary parasites which lack green chlorophyll and suck their nutriment from other plants' roots, are the bedstraw and oxtongue broomrapes Orobanche caryophyllacea and $O$. loricata, both on the named host plants in East Kent, and thistle broom- 